\title{
ARE THERE DIFFERENCES IN THE MORPHOLOGY OF COMMUNAL MOUNDS OF OVERWINTERING MOUND-BUILDING MICE (MUS SPICILEGUS PETÉNYI, 1882) IN SLOVAKIA?
}

\author{
Alexander Csanády ${ }^{1}$, Michal Stanko ${ }^{2,3}$ and Ladislav Mošanskí ${ }^{2}$ \\ ${ }^{1}$ Department of Biology, Faculty of Humanities and Natural Sciences, University of Prešov \\ 17. novembra 1, 08001 Prešov, Slovakia; \\ E-mail: alexander.canady@gmail.com; https://orcid.org/0000-0003-1679-3562 \\ ${ }^{2}$ Institute of Parasitology, Slovak Academy of Science, SK-040 01 Košice, Slovakia \\ E-mail: stankom@saske.sk; https://orcid.org/0000-0002-9917-2421; E-mail: mosansky@saske.sk \\ ${ }^{3}$ Institute of Zoology, Slovak Academy of Science, SK-040 01 Košice, Slovakia
}

To describe variations in overwintering mounds and nest sizes of the mound-building mouse (Mus spicilegus), mounds were measured and excavated in 16 locations in southeastern and south-western Slovakia in autumn and/or winter between 2002 and 2011. The study was carried out in fields where crops had been harvested before the investigations. All evaluated mounds were located in agroecosystems with sunflower, maize and wheat crops as well as on field margins. Comparisons were made by basis of their dimensions (length, width, height, volume, nest depth) and the plant material collected. Data between the sampling groups were compared using the Mann-Whitney U test and Kruskal-Wallis H test. Spearman's correlation $\left(\mathrm{r}_{\mathrm{s}}\right)$ was used to examine the relation between mound and nest size (dependent variables) and four independent variables (season, geomorphological, soil and field types). We found habitat and soil-related variation in mound size which also diminished by season. Mounds vary in size among geographical populations, i.e. mounds from south-eastern Slovakia (basin and lowland) had larger dimensions than those from south-western Slovakia (upland). In contrast, we didn't confirm a correlation between the sizes of the mounds and the nests.

Keywords: mound-building mouse, variation, morphometry, mounds, nests, Slovakia.

\section{INTRODUCTION}

The mound-building mouse, Mus spicilegus Petényi, 1882, represents a relatively specialized species, strictly wild and living in a small number of habitats away from human settlements (Macholán 1999). A specific ecological and ethological feature of M. spicilegus is its grain-hoarding activity. In autumn, groups of several individuals build special mounds in which they store the seeds of weeds and cultural crops for the winter and in which they prepare subterranean nests (Naumov 1940, Pisareva 1948, Hamar 1960, Mikeš 1971, Muntyanu 1990, Unterholzner \& Willenig 2000, ČanÁdy et al. 2005, 2009, Hölzl et al. 2009, 2011a, b, SzEnczi et al. 2011, 2012, SimeonovsKa-Nikolova et al. 2014). These mounds have several functions, such as food storage and/or 
thermoregulation. However, knowledge and opinions on the morphology of the mounds, their significance and construction, have changed over time, and at present many questions are inadequately answered.

The first important knowledge on the beginning and end of construction, dimensions, nesting location, burrow system and plant composition of the mounds came from Ukraine (Naumov 1940, Pisareva 1948). Later, Sokolov et al. (1990) summarized older literature and reported new data from Ukraine and Moldova. Similarly, Zagorodnyuk and Berezovský (1994) also referred to the occurrence and above-ground dimensions of these mounds in Ukraine.

From 1948-1964 Mıкеš (1971), working in Vojvodina (then Yugoslavia, today Serbia), thoroughly examined not only the selected aspects of species ecology but also paid great attention to the structure of the winter reservoirs, the underground system of burrows and their nesting chambers.

Further data from Romania (Hamar 1960), Austria (Festetics 1961, UNTerholzner \& Willenig 2000, Hölzl et al. 2009, 2011a, b), Moldova (Muntyanu 1990, Simeonovska-Nikolova et al. 2014), Bulgaria (Simeonovska-Nikolova et al. 2014) and Hungary (BiHARi 2004, 2007, Szenczi et al. 2011, 2012) also confirmed previous observations on mound morphology.

On the basis of the presence of typical winter mounds, several authors (KrišTofí́ \& Danko 2003a, b, MašÁn \& Stanko 2005, ČAnÁdy et al. 2005, 2007, 2009, HölzL et al. 2009, 2011a, b, VÁrfalvyová et al. 2010, 2011) have reported on the occurrence of M. spicilegus in Slovakia.

All of the above-cited studies showed that in most cases, the mounds were found on field margins, boundaries, roadsides and wastelands, that is, in places where the weeds (Setaria verticillata, Atriplex tatarica, Amaranthus spp., Chenopodium spp. etc.) were abundant, as well as in weedy fields of perennial grasses. As has been noted by the cited authors, mounds inhabited by M. spicilegus are usually relatively large, in most cases oval and more rarely cone-shaped structures. The mounds represent an accumulation of seeds, spikes and other kinds of plant materials, covered with earth. Cultural seeds (sunflowers, corns, wheat) are listed less frequently (e.g. MiкEš 1971, SoкоLov et al. 1990). Construction of mounds occurs from mid-August to mid-November, with peak construction in mid- to late-September after seed maturation of forage plants and the cessation of breeding (SoкоLov et al. 1990, 1998, UNTERHOLZNER \& WilleNig 2000, ČANÁDy et al. 2005, 2009). SoKolov et al. (1990) consider stable settlement of the same habitat under current agricultural conditions to be not possible, because intensive crop harvesting and ploughing of the stubble force the rodents to migrate and to concentrate in certain habitats. In this respect, there are currently very few natural steppes, and the main places of survival of $M$. spicilegus are fields, unploughed areas, windbreaks and habitats near roads. According to Naumov (1940), a shifting of the population is taking place. In autumn, individuals occur mainly in crop fields. Ploughing 
destroys most of the mounds, so individuals colonize stands of grass, stubble, and areas near roads. During the early sowing of summer crops individuals are concentrated in the surrounding ruderal areas, and during the ripening of cereals, they move into the fields. In contrast, during the harvest, they are dispersed into the surroundings. The total number of mounds in the same habitat may also vary considerably depending on the number of weeds in the individual areas (SoKоLov et al. 1990). Frequent agro-technical interventions aimed at destroying weeds may significantly affect the overall abundance of mice in the study of habitat type. In general, ploughing in the autumn has a negative impact on the survival of the species population (SoкоLov et al. 1990, Muntyanu 1990). Unterholzner and Willenig (2000) studied the settlements of individual sites for mounds in Austria. During a four-year period they found the frequency of mounds to vary in different habitats. Nevertheless, they confirmed the incidence of $M$. spicilegus individuals in a particular type of habitat being largely dependent on the presence of a wide range of grasses and weeds.

The rebuilding of mounds within three to four days following their destruction by ploughing has also been observed (Muntyanu 1990, SoкоLov et al. 1990, ČANÁdy et al. 2009). The mounds vary in size and composition among geographical locations (BiHARI 2004, 2007, Hölzl et al. 2009, SzEnczi et al. 2011, 2012, Simeonovska-Nikolova et al. 2014), which may be the result of genetic variation among mice, environmental differences or both. Comparative observations in natural and laboratory conditions (Pisareva 1948, Sokolov et al. 1990, Serra et al. 2011, Hurtado et al. 2013) have shown that the construction of a single mound takes from some days to four weeks. UNTERHOLZNER \& WiLLENIG (2000) reported that the collection of M. spicilegus stocks is specific for two reasons. The first is to collect and store the stock on the surface of the soil along with the soil cover. The second is the collective construction of these reservoirs. SERRA et al. (2011) found a behavioural differentiation during a collective building task under laboratory conditions. They showed that from a group of six individuals, only two mice (called carriers) transported $80 \%$ of the building material, whereas the contribution of the remaining mice was weak or even non-existent. Similarly, Hurtado et al. (2013) showed that the process includes several successive phases. Mainly, the transport and piling up of different kinds of plant materials coupled with covering the mound with earth and digging the galleries. Moreover, laboratory experiments revealed that within a group of individuals, not all individuals were equally involved in the construction of the hills. According to findings, they concluded that at least under controlled laboratory conditions, a task-related specialization occurred during the collective construction of the mound.

The main goal of our study was to describe variation in mound and nest morphology and to examine whether different geographical populations 
(i.e. basin, lowland and upland on a regional level), habitat (i.e. type of field crops), soil type (hard and/or soft) and seasonal (autumn and/or winter) differences influence the size of the mounds. Considering that the season can affect the size of the mounds, we expected to find significant variations in mound parameters mainly in relation to seasonal differences. Szenczi et al. (2011) and Simeonovska-Nikolova et al. (2014) noted that mound size is correlated positively with the number of mice. In contrast, HöLzL et al. (2009) showed that mound size is independent of the number of inhabitants within the mounds. In this context we expected a positive correlation between the size of the mounds and the nests, indicating that more individuals are involved in the construction of larger mounds.

\section{MATERIAL AND METHODS}

The mounds, which were located in fields harvested prior to the investigations or without agricultural activity, i.e. abandoned fields or field margins and drainage canals with ruderal vegetation, were measured and excavated at 16 localities in Slovakia during the period 2002-2011 (Table 1). All mounds occurred on stubble and weedy fields grown mainly with Solidago gigantea, Artemisia spp., Setaria spp., Stipa spp., Chenopodium spp., and Amaranthus spp. etc. The main crops during the vegetation season at the evaluated sites were maize, wheat and sunflower. After harvesting of the fields, the mounds were sought in these habitats and subsequently were measured, documented and marked to avoid recounting. In total 306 mounds were evaluated in a basin, 51 from lowland and finally 19 from upland. We measured three mound parameters (length, width and height). Then the hills were excavated to find the subterranean nest, which were also measured: the nest length, i.e. the longer radius; the nest width, i.e. the shorter radius; and its depth under soil surface (ČANÁDY et al. 2009).

We also estimated the dominant species of stored seeds and other kinds of different plants. The volume of the mounds was calculated using the formula for ellipsoid-base cones $\left(1 / 3^{*} r_{1}{ }^{*} r_{2}{ }^{*} h^{*} \pi\right)$, where $r_{1}$ is the longer radius, $r_{2}$ is the shorter radius, and $h$ is the height (SzEnCzi et al. 2011).

All mounds were divided into four groups as independent variables (Table 2): (1) the geomorphological type i.e. from different geographical populations: basin (seven sites from the Košická kotlina basin), lowland (five sites from the Východoslovenská nížina lowland) and upland (four sites from the Ipel'ská and Hronská pahorkatina upland); (2) season: autumn and winter; (3) soil type: hard i.e. clay and soft i.e. sandy; and finally (4) field type: harvested crops (maize or sunflower), stubble and abandoned fields.

During the excavation of mounds were also capture mound-building mice which were housed in the laboratory and then evaluated. The research conformed to the national and international requirements for ethical attitude towards animals (see Acknowledgements).

The normality of the dataset was tested using the D'Agostino-Pearson omnibus test and the Shapiro-Wilk normality test. The evaluated mound and nest features are expressed by range values and means $(\mathrm{M})$ with standard deviation (SD). Spearman's correlation $\left(\mathrm{r}_{\mathrm{s}}\right)$ was used to examine the relationships between mound and nest sizes as dependent variables and four independent variables. To estimate if there are variations in mound size between the above-mentioned groups, data were compared using the Mann-Whitney U test 
Table 1. Sites used to sample and excavate mounds $(n=376)$ of Mus spicilegus for mound morphology.

\begin{tabular}{|c|c|c|c|c|c|c|}
\hline $\begin{array}{l}\text { Settlement } \\
\text { (site) }\end{array}$ & GPS coordinates & $\begin{array}{l}\text { Geo } \\
\text { type }\end{array}$ & Soil type & Season & Field type & $\begin{array}{c}\text { Sample } \\
\text { size }\end{array}$ \\
\hline Belža & $48.584 \mathrm{~N}, 21.264 \mathrm{E}$ & basin & clay & autumn & $\begin{array}{l}\text { harvested, stub- } \\
\text { ble, abandoned }\end{array}$ & 20 \\
\hline Bielovce & $47.985 \mathrm{~N}, 18.762 \mathrm{E}$ & upland & clay & autumn & stubble & 5 \\
\hline Bočiar & $48.586 \mathrm{~N}, 21.234 \mathrm{E}$ & basin & clay & autumn & stubble & 16 \\
\hline Demandice & $46.228 \mathrm{~N}, 47.787 \mathrm{E}$ & upland & clay & autumn & harvested & 2 \\
\hline Gbelce & $51.599 \mathrm{~N}, 29.049 \mathrm{E}$ & lowland & clay & autumn & $\begin{array}{l}\text { harvested, } \\
\text { stubble }\end{array}$ & 7 \\
\hline Grajciar & $48.597 \mathrm{~N}, 21.264 \mathrm{E}$ & basin & clay & $\begin{array}{l}\text { autumn, } \\
\text { winter }\end{array}$ & abandoned & 2 \\
\hline Haniska & $48.619 \mathrm{~N}, 21.261 \mathrm{E}$ & basin & clay & autumn & $\begin{array}{l}\text { harvested, } \\
\text { stubble }\end{array}$ & 21 \\
\hline Kechnec & $48.552 \mathrm{~N}, 21.241 \mathrm{E}$ & basin & clay & $\begin{array}{l}\text { autumn, } \\
\text { winter }\end{array}$ & $\begin{array}{l}\text { harvested, stub- } \\
\text { ble, abandoned }\end{array}$ & 208 \\
\hline $\begin{array}{l}\text { Královský } \\
\text { Chlmec }\end{array}$ & $48.416 \mathrm{~N}, 18.016 \mathrm{E}$ & lowland & clay & winter & stubble & 10 \\
\hline Mužla & $47.816 \mathrm{~N}, 18.550 \mathrm{E}$ & upland & clay & autumn & stubble & 7 \\
\hline Sokol'any & $48.603 \mathrm{~N}, 21.227 \mathrm{E}$ & basin & clay & autumn & stubble & 35 \\
\hline Svätuše & $48.400 \mathrm{~N}, 21.917 \mathrm{E}$ & lowland & $\begin{array}{l}\text { clay, } \\
\text { sandy }\end{array}$ & $\begin{array}{l}\text { autumn, } \\
\text { winter }\end{array}$ & $\begin{array}{l}\text { stubble, aban- } \\
\text { doned }\end{array}$ & 23 \\
\hline Valaliky & $48.637 \mathrm{~N}, 21.268 \mathrm{E}$ & basin & clay & winter & stubble & 4 \\
\hline Malé Kosihy & $47.932 \mathrm{~N}, 18.768 \mathrm{E}$ & upland & clay & autumn & stubble & 5 \\
\hline Vel'ký Kamenec & $48.370 \mathrm{~N}, 21.825 \mathrm{E}$ & lowland & sandy & $\begin{array}{l}\text { autumn, } \\
\text { winter }\end{array}$ & abandoned & 6 \\
\hline Vel'ký Horeš & $48.374 \mathrm{~N}, 21.888 \mathrm{E}$ & lowland & clay & autumn & abandoned & 5 \\
\hline
\end{tabular}

and Kruskal-Wallis $\mathrm{H}$ tests. All analyses were performed using the statistical analysis system GraphPad Prism, version 5.01 (GraphPad Software, Inc., San Diego, California, USA).

\section{RESULTS}

Variation in mound and nest morphology was shown in Table 2. In 78 excavated mounds the reservoir was formed from parts of different plant species (Fig. 1). Among them, the most abundant plant species were bristle grass, Setaria spp. (L.) P.Beauv (80.8\%); mugwort, Artemisia vulgaris L. (2.6\%); European goldenrod, Solidago virgaurea L. (2.6\%); and tansy, Tanacetum vulgare L. $(1.3 \%)$. In addition, the mice also collected grains of sunflower, Helianthus annuus L. (11.5\%) and oat Avena sativa L. (1.3\%), which were also recorded in the stocks. For 14 nests, it was confirmed that nesting material was formed mainly from Setaria spp. (64.3\%), Avena sativa (21.4\%) and Zea mays (14.3\%). 


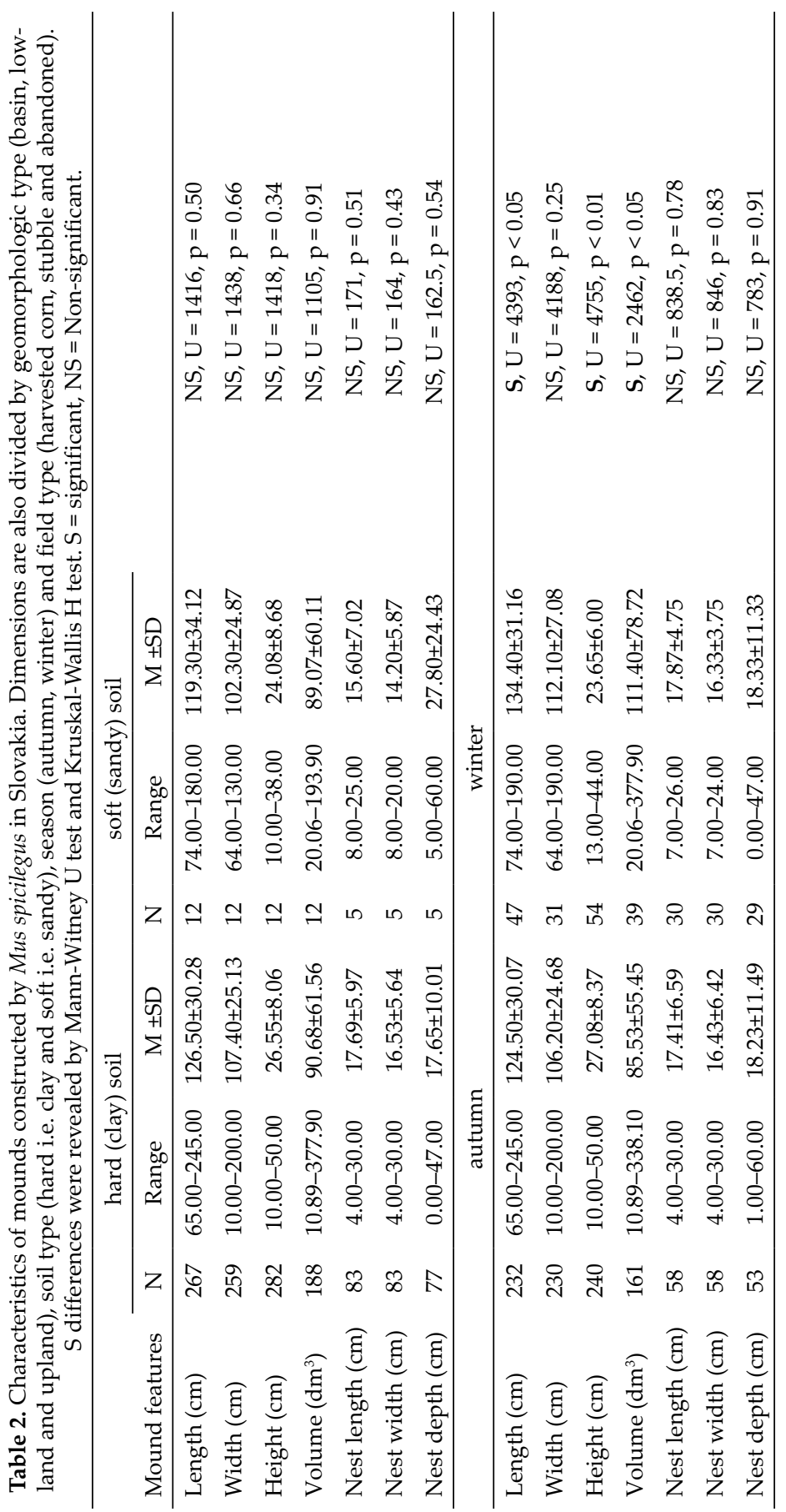




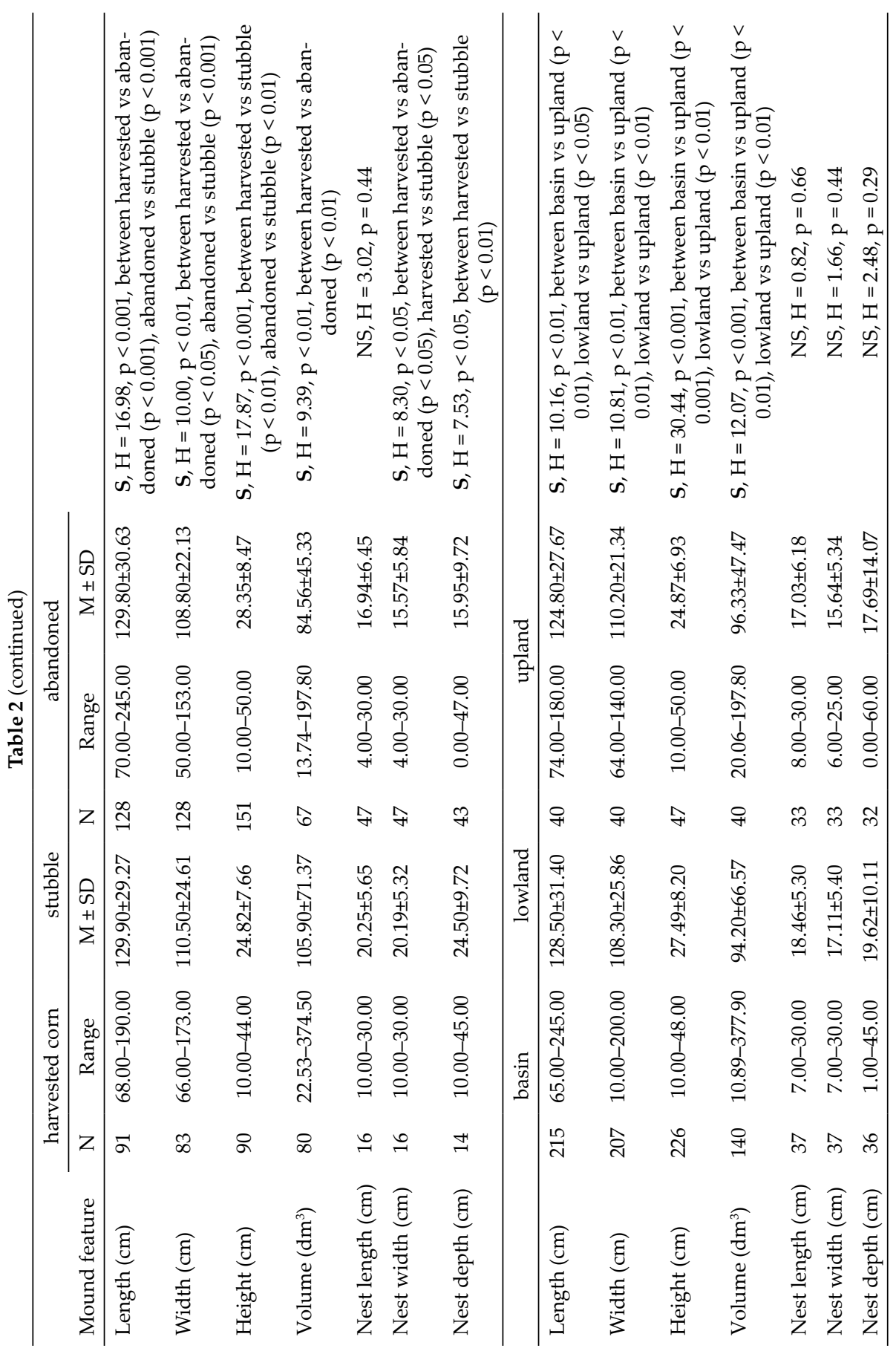


Comparisons between geomorphological types

The results showed differences in the mounds and parameters between geomorphological types - basin, lowland and upland. In general, the dimensions of the mounds and nests from the basin had statistically higher values (Table 2) than those from the upland. In contrast, the differences between the mounds from the basin and lowland were not very large and were not statistically significant. Although statistically significant differences were confirmed between mounds from the basin and upland, it should be stressed that there was a significant disproportion between the sample sizes that could have affected the result. Correlation coefficients between geomorphological types and mound dimensions did not confirm any of the relationships (Table 3).

\section{Comparisons between field types}

When comparing the results by field type, differences were again confirmed, especially between managed areas (cultivated or harvested field) and abandoned areas (Table 2). The dimensions of the mounds had higher values in cultivated fields than on abandoned areas, and these differences were statistically very significant, mainly in the height and volume of the hills. On the contrary, the size of the nests and their depths in the soil were not affected.

\begin{tabular}{|c|c|c|c|}
\hline $\begin{array}{r}100 \% \\
90 \% \\
80 \% \\
70 \% \\
60 \% \\
50 \% \\
40 \% \\
30 \% \\
20 \% \\
10 \% \\
0 \%\end{array}$ & rysrys & 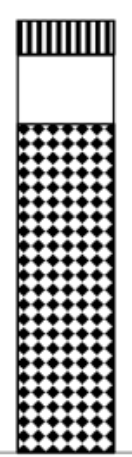 & \& \\
\hline & Abandoned & Stubble & Harvested \\
\hline -Avena sativa & 1 & & \\
\hline$\nabla$ Artemisia vulgaris & 2 & & \\
\hline - Tanacetum vulgare & & 2 & \\
\hline Solidago virgaurea & & & 2 \\
\hline$\square$ Helianthus annuus & 5 & 4 & \\
\hline Setaria spp. & 36 & 19 & 8 \\
\hline
\end{tabular}

Fig. 1. Plant composition by species of mounds $(\mathrm{n}=78)$ of Mus spicilegus 
Table 3. Spearman's correlation matrix of mound and nest features with seasonal, field, soil and geomorphological types. Significant correlations higher than $\mathrm{p}<0.01$ are in bold type.

\begin{tabular}{lcccccccccc}
\hline & Length & Width & Height & $\begin{array}{c}\text { Vol- } \\
\text { ume }\end{array}$ & $\begin{array}{c}\text { Nest } \\
\text { length }\end{array}$ & $\begin{array}{c}\text { Nest } \\
\text { width }\end{array}$ & $\begin{array}{c}\text { Nest } \\
\text { depth }\end{array}$ & $\begin{array}{c}\text { Field } \\
\text { type }\end{array}$ & $\begin{array}{c}\text { Sea- } \\
\text { son }\end{array}$ & $\begin{array}{c}\text { Soil } \\
\text { type }\end{array}$ \\
\hline Width & $\mathbf{0 . 8 4}$ & & & & & & & & & \\
Height & $\mathbf{0 . 3 5}$ & $\mathbf{0 . 4 0}$ & & & & & & & & \\
Volume & $\mathbf{0 . 8 4}$ & $\mathbf{0 . 8 7}$ & $\mathbf{0 . 7 4}$ & & & & & & & \\
Nest length & 0.15 & 0.20 & 0.09 & 0.15 & & & & & & \\
Nest width & 0.13 & 0.16 & 0.06 & 0.12 & $\mathbf{0 . 8 9}$ & & & & & \\
Nest depth & 0.05 & 0.03 & 0.16 & 0.06 & $\mathbf{0 . 3 0}$ & $\mathbf{0 . 3 4}$ & & & & \\
Field type & 0.02 & 0.03 & 0.22 & -0.12 & -0.13 & -0.21 & -0.26 & & & \\
Season & 0.13 & 0.07 & -0.18 & 0.15 & 0.03 & -0.02 & -0.01 & -0.18 & & \\
Soil type & -0.04 & -0.03 & -0.06 & -0.01 & -0.07 & -0.09 & 0.07 & -0.14 & 0.18 & \\
$\begin{array}{l}\text { Geomor- } \\
\text { phology }\end{array}$ & -0.14 & -0.09 & -0.28 & -0.10 & -0.05 & -0.01 & -0.17 & 0.12 & 0.14 & $\mathbf{0 . 3 3}$ \\
type & & & & & & & & & & \\
\hline
\end{tabular}

The weak relationship between height and type of agricultural activity was confirmed by correlation analysis (Table 3).

\section{Comparisons between seasons}

Different values were also confirmed for mounds measured in autumn (September-November) and winter (December-March, Table 2). Although the results point to larger dimensions in length and width, they can be misleading. It should be emphasized that the dimensions presented are values measured either in autumn or only in winter, and we cannot assess their possible reduction due to weather factors. A significant difference in height (and hence volume) could be directly affected by these weather factors. As expected, the depth of the nest is not affected by the season, since they are built exclusively in autumn. However, the size of the nests may be smaller in the winter due to the rotting process. However, we did not find any differences (Tables $2 \& 3$ ).

\section{Comparisons between areas with different soil types}

Soil type was an insignificant factor that affected the dimensions of the mounds (Tables $2 \& 3$ ), with exception of the depth of the nests. In one case the nest was found not under the soil surface but directly in the mound (site Královský Chlmec in lowland with clay soil). This may have been related to the groundwater level, which may have an impact on nest construction made well below the surface. Likewise, sandy soil allows mice to dig the nest 
and burrows even deeper $(60 \mathrm{~cm}$ nest depth and burrows up to $70 \mathrm{~cm}$ below ground at the Vel'ký Kamenec lowland site). Nevertheless, the sample size from soft (sandy) soil was too small to estimate the importance of this factor on the building of hills.

\section{DISCUSSION}

Several authors have mentioned the selection of habitats by individuals of $M$. spicilegus, with an emphasis on the relative abundance species in different habitats (Naumov 1940, Pisareva 1948, Hamar 1960, Mikeš 1971, Sokolov et al. 1990, Muntyanu 1990, Simeonovska-Nikolova \& Gerasimov 2000, Unterholzner \& Willenig 2000, Hölzl et al. 2009, 2011a, b, Szenczi et al. 2011, SimeonovsKa-Nikolova et al. 2014). Our findings confirmed that mound-building mice built their winter hills not only directly in fields but also in field margins, windbreaks or drainage canals. These places represent abandoned areas where the mice survive and where they are not exposed to intensive agricultural activities. However, the dimensions of the hills built on these habitat types were smaller than those in the fields. Moreover, these habitats are less suitable for the construction of winter reservoirs.

We also found differences in the dimensions of the mounds and nests according to different geomorphological type, as well as by different season. Simeonovska-Nikolova et al. (2014) showed that the volume of the mounds was smaller in the spring in comparison with the autumn, which may be due to the subsidence of mounds. This observation was partially in accordance with our findings. Differences in the dimensions of the hills measured in autumn and winter were significant, although it should be noted that our measurements were not made on the same mounds, and therefore we cannot confirm their change during the winter. Dimensional changes during the winter can be caused either by consumption of the seed reservoir (SoкоLov et al. 1990) or by the influence of weather, i.e. wind, rain or snow (SimeonovskANikolova et al. 2014). Szenczi et al. (2011) and Simeonovska-Nikolova et al. (2014) found a correlation between mound size and mice captured per mound and suggested that larger mounds were built by more mice (but see ČANÁDY et al. 2009). Our results did not confirm the correlation between the size of hills and nests and are in accordance with data obtained by HöLzL et al. (2009), suggesting that mound size is independent of the number of inhabitants within the mounds. However, our findings were in agreement with the behavioral differentiation of individuals during the collective construction of the mound, found by Serra et al. (2011) and Hurtado et al. (2013) should be done as well. Moreover, mound height (and not their volume) deteriorate by season and 
size is dependent on soil type and even agricultural activities altering local soil characteristics and may affecting digging in mice.

On the other hand, the amount and type of plant material that mice have available for construction may explain the variation among mounds (HöLzL et al. 2009). In Slovakia (ČANÁdy et al. 2009, together with results showed in this study) the plants used by mice as building materials were similar as those observed by other authors (Naumov 1940, Pisareva 1948, Hamar 1960, Mikeš 1971, Soкоlov et al. 1990, Hölzl et al. 2009, UnterholzNer \& Willenig 2000, Szenczi et al. 2011a, Simeonovska-Nikolova et al. 2014). According to BiHARI (2004), Hölzl et al. (2011), Szenczi et al. (2011) the stored vegetable matter does not, or not exclusively, serve as food. Recent studies indicate that the mounds might play an insulating role and that the plant fill plays a major role in their thermal insulation and waterproofing properties. The construction of a mound and nest might help reduce temperature fluctuations (SzEnczi et al. 2012). Nevertheless, our observations of excavated mounds, when we found in six mounds also burrows (6.8\%) as well as the four dead M. spicilegus specimens (18 December 2010, Kechnec) directly in the food reservoir, confirmed that the reservoir also plays the role of a food source. The thermoregulatory function of the mounds is also questionable. During the search for the nesting chambers many nests were placed very eccentrically, and in many cases the nest was not even found at a greater depth under the hillocks. If we assume that the nesting chamber was most likely placed not directly under the mound or more than $30 \mathrm{~cm}$ underground $(\mathrm{n}=14)$, then the insulating function does not have any effect on the nest itself. It is also worth mentioning that one nest was found directly within a reservoir, i.e. $13 \mathrm{~cm}$ above the soil surface and 10 $\mathrm{cm}$ under the top of the mound (26 March 2010, Kechnec). Putting the nests within the reservoir $(1.1 \%, \mathrm{n}=1)$ or close to the soil surface $(1.1 \%, \mathrm{n}=1)$ were also associated with a higher level of groundwater. The one nest were found in lowland habitats (Východoslovenská nížina) where ground water table is close to surface but second was found on locality from Košická kotlina basin.

The present study extends the knowledge about the morphology of the mounds, the location and function of the nests of M. spicilegus in Slovakia and the factors that influence them. In summary, we found variation in the size of the mounds constructed and inhabited by Mus spicilegus. We showed differences in size among geographical regions and that mounds from south-eastern Slovakia (basin and lowland) were larger than those from the south-western parts (upland). We also confirmed that field type and season influence the size of the mounds. In contrast, we did not find any correlation between the size of hills and nests. We still do not know how many mice may participate in mound-building in nature condition. Therefore, future field studies are needed to understand these issues. Moreover, in some regions this species is 
considered an agricultural pest while in others, the loss of grasslands and agricultural intensification may cause population declines. Our findings could be relevant to various conservation and management actions.

Acknowledgements - We would like to thank Monika Onderová for help in fieldwork. The handling of small mammals complies with the laws of the Slovak Republic (No. 2971108/06). This work was supported by grants VEGA 1/0084/18, APVV-14-0274 and APVV-15-0134. Our thanks also go to anonymous referees for their valuable comments on the manuscript, and to David McLean for revising the English language.

\section{REFERENCES}

BiHARI, Z. (2004): A güzüegér magyarországi elterjedése és építő tevékenységének jellemzői. - Vadbiológia 10: 107-114.

Bihari, Z. (2007): Güzüegér. Pp. 195-196. In: Bihari, Z., Csorba, G. \& Heltai, M. (eds): Magyarország Emlőseinek Atlasza. - Kossuth Kiadó. Budapest.

ČAnÁdy, A., MošAnskx́, L. \& Stanko, M. (2005): First knowledge about morphology of the mounds built by mound-building mouse (Mus spicilegus Petényi, 1882) in Eastern Slovakia. - Natura Carpatica 46: 159-164.

ČAnÁdy, A., MošAnskÝ, L., StANKo, M. \& FričovÁ, J. (2007): Small mammals (Insectivora, Rodentia) of the Industrial park Kechnec (Košická kotlina basin, East Slovakia) - Natura Carpatica 48: 153-162.

Čanády, A., Mošanský, L. \& Stanko, M. (2009): First knowledge of winter ecology of the mound-building mouse (Mus spicilegus Petényi, 1882) from Slovakia - Acta Zoologica Bulgarica 61: 79-86.

Festetics, A. (1961): Ährenmaushügel in Österreich. - Zeitschrift für Säugertierkunde 26: 112-125.

HAMAR, M. (1960): Systematics, distribution and ecology of mound-building mouse (Mus musculus spicilegus Petényi, 1882) in Rumanien. - Revue de Biologie (Bucarest) 5: 207219.

Hammer, Ø., Harper, D. A. T. \& Ryan, P. D. (2001): PAST: Paleontological statistics software package for education and data analysis. - Palaeontologia Electronica 4: 1-9.

Hölzl, M., Hoi, H., Darolová, A., Krišsofík, J. \& Penna, D. J. (2009): Why do the mounds of Mus spicilegus vary so much in size and composition? - Mammalian Biology 74: 308-314. https://doi.org/10.1016/j.mambio.2009.02.004

Hölzl, M., Hoi, H., Darolová, A. \& Krištofír, J. (2011a): Insulation capacity of littermounds built by Mus spicilegus: physical and thermal characteristics of building material and the role of mound size. - Ethology, Ecology and Evolution 23: 49-59. https:// doi.org/10.1080/03949370.2010.529827

Hölzl, M., Krištofík, J., Darolová, A. \& Hoi, H. (2011b): Food preferences and moundbuilding behaviour of the mound-building mice Mus spicilegus. - Naturwissenschaften 98: 863-870. https://doi.org/10.1007/s00114-011-0837-5 
Hurtado, M. J., Fénéron, R. \& Gouat, P. (2013): Specialization in building tasks in the mound-building mouse, Mus spicilegus. - Animal Behaviour 85: 1153-1160. https:// doi.org/10.1016/j.anbehav.2013.03.020

KRIŠTofík, J. \& DANKo, Š. (2003a): Distribution of Mus spicilegus (Mammalia: Rodentia) in Slovakia. - Lynx (Praha) 34: 55-60.

KRIŠTOFÍ, J. \& DANKO, Š. (2003b): First findings and evidences of steppe mouse (Mus spicilegus Petényi, 1882) in the Východoslovenská rovina plain and Košická kotlin basin. - Natura Carpatica 44: 279-282.

Macholán, M. (1999): Mus spicilegus Petényi, 1882. Pp. 288-289. In: Mitchell-Jones, A. J., Amori, G., Bogdanowicz, W., Kryštufek, B., Reijnders, P. J. H., Spitzenberger, F., Stubbe, M., Thissen, J. B. M., Vohralík, V. \& Zima, J. (eds): The atlas of European mammals. Academic Press, London.

MašÁn, P. \& Stanko, M. (2005): Mesostigmatic mites (Acari) and fleas (Siphonaptera) associated with nests of mound-building mouse Mus spicilegus Petényi, 1882 (Mammalia, Rodentia). - Acta Parasitologica 50: 228-234.

MiкEš, M. (1971): Ecological investigation on Mus musculus hortulanus Nordmann in Vojvodina. - Zbornik za prirodne nauke Matice srpske 40: 52-129.

MuntYanu, A. I. (1990): Ecological features of an overwintering population of the hillock mouse (M. hortulanus Nordm.) in the south-west of the U.S.S.R. - Biological Journal of the Linnean Society 41: 73-82. https://doi.org/10.1111/j.1095-8312.1990.tb00822.x

Naumov, N. P. (1940): Ekologija kurgančikovoj myši Mus musculus hortulanus Nordm. Trudy Instituta evolyutsionnoi morfologii, Academii Nauk SSSR 3: 33-76.

Pisareva, N. A. (1948): Ecology and systematics of mound-building mouse. - Sborník Rabot Biologicheskogo Faculteta. Moscow University 32: 68-71.

Serra, J., Hurtado, M. J., Le Negrate, A., Feron, C., Nowak, R. \& Gouat, P. (2011): Behavioral differentiation during collective building in wild mice Mus spicilegus. - Behavioural Processes 89: 292-299. https://doi.org/10.1016/j.beproc.2011.12.007

Simeonovska-Nikolova, D. \& Gerasimov, S. (2000): Seasonal changes of some population characteristics of M. spicilegus in North Bulgaria. - Acta Zoologica Bulgarica 52: 81-90.

Simeonovska-Nikolova, D., Beltcheva, M., Larion, A., Nistreanu, V. \& Metcheva, R. (2014): Variations in the mound size of mound-building mouse, Mus spicilegus between Bulgaria and Moldova. - Bulgarian Journal of Agricultural Science 20: 125-128.

Sokolov, V. E., Kotenkova, E. V. \& Ljaljukhina, S. I. (1990): Biology of house mouse and mound-building mice. - Nauka, Moskva, 207 pp.

Sokolov, V. E., Koтenkova, E. V. \& Michailenko, A. G. (1998): Mus spicilegus. - Mammalian Species 592: 1-6. https://doi.org/10.2307/3504484

Szenczi, P., Bánszegi, O., Dúcs, A., Gedeon, C. I., Markó, G., Németh, I. \& Altbä̈cker, V. (2011): Morphology and function of communalmounds of overwintering moundbuilding mice (Mus spicilegus). - Journal of Mammalogy 92: 852-860. https://doi.org /10.1644/10-MAMM-A-258.1

Szenczi, P., Kopcsó, D., BÁnszegi, O. \& Altbäcker, V. (2012): The contribution of the vegetable material layer to the insulation capacities and water proofing of artificial Mus spicilegus mounds. - Mammalian Biology-Zeitschrift für Säugetierkunde 77: 327-331. https://doi.org/10.1016/j.mambio.2012.03.003

Unterholzner, K. \& Willenig, R. (2000): Zu Ökologie, Verhalten und Morphologie der Ährenmaus Mus spicilegus Petényi, 1882. - Biosystematics und Ecology Series, Verlag Öesterreichischen Akademie der Wissenschaften, Wien 17: 1-88. 
Várfalvyová, D., Miklisová, D. \& Stanko, M. (2010): Charakteristika spoločenstiev mezostigmátnych roztočov (Mesostigmata) v hniezdach Mus spicilegus (Rodentia, Muridae) na Slovensku. - Folia Faunistica Slovaca 15: 13-18.

VÁrfalvyová, D., Stanko, M. \& Miklisová, D. (2011): Composition and seasonal changes of mesostigmatic mites (Acari) and fleas fauna (Siphonaptera) in the nests of Mus spicilegus (Mammalia: Rodentia). - Biologia 66: 528-534. https://doi.org/10.2478/s11756 -011-0050-1

Zagorodnyuk, I. V. \& Berezovsky, V. I. (1994): Mus spicilegus (Mammalia) in the fauna of Podolia and the northern border of its range in Eastern Europe. - Zoologicheskii Zhurnal 73: 110-119.

Received January 28, 2019, accepted April 5, 2019, published May 31, 2019 